\title{
Evaluation of Dietary Supplement Intake (Yeast Tablets) on Pregnant Albino Rats and Their Fetuses (Implications of Yeast Tablets on Rats \& Fetuses)
}

\author{
Amel Ramadan Omar ${ }^{1 *}$, Eman Youssri Salah El-Din ${ }^{1}$; Heba Ali Abdelrahman', Hanan \\ Ramadan Mohamed'. \\ ${ }^{1}$ Cairo University, Giza, Egypt.
}

\begin{abstract}
Histopathological studies in placenta, liver, kidney, apoptotic DNA damage and p53 mutation estimation of pregnant rats and their offspring exposed to dietary supplement yeast tablets, were carried out.

Pregnant female albino rats were orally administrated yeast tablets at concentration $41.1 \mathrm{mg} / \mathrm{kg}$ during gestation period. Hematoxylin and eosin stained sections were used for examination. Neutral comet assay was performed to assess the apoptotic DNA damage and single strand conformational analysis was performed to screen the mutations inductions in p53 exons 7 and 8. Statistical analysis is applied to found the relation of apoptotic fraction in liver, kidney and placenta of pregnant rats and their offspring.

Oral administration of yeast tablets to pregnant rats induced histopathological alterations in the hepatic, kidney tissues of both mothers and fetuses and placenta tissues. In addition, it induced apoptotic DNA damage as revealed by the significant elevations in apoptotic fractions $(p<0.001)$ in liver and kidney tissues of both treated rats and their fetuses and even in the placenta ( $p<0.001)$. On contrary, no any mutation was induced in 553 exons 7 and 8 by yeast administration either in pregnant rats or their fetuses examined organs.

The histopathological changes and apoptotic DNA damage recorded in female rats and fetus's tissues which can result in definite hormonal and atrophic effects on adult rats and the fetuses, the possibility of early or late physiological effects in the mature and progeny under the administration of yeast tablets must be taken into consideration.
\end{abstract}

Keyword: Alteration, Comet assay, Single strand conformational analysis, Yeast tablets

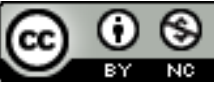

*Author for correspondence: amel_cu1983@yahoo.com 


\section{INTRODUCTION}

Yeast-based products have ability to enhance immunity and health during stressful events by acting as immunomodulators and biological response modifiers, so justifying some of the negative effects associated with pathogenesis and morbidity [1]. Also, probiotics have the ability to stimulate the intestinal immune system and increase the production of antimicrobial peptides and cytokines in the intestinal tract to modulate the intestinal immune functions [2].

Brewer's yeast is actually a fungus, an organism called Saccharomyces cerevisiae. It is often used to make beer, hence the name, but may be part of other nutritional supplements. Brewer's yeast contains many different vitamins, including B-complex, such as thiamine, niacin and riboflavin, and minerals as Selenium. Brewer's yeast, a type of nutritional supplement, is high in chromium and other nutrients that are important for the body. Chromium apparently has a role in maintaining proper carbohydrate and lipid metabolism in mammals [3]. Because this role is probably involved in potentiating of insulin signaling, chromium dietary supplementation has been postulated to have effects on body composition, including reducing fat mass and increasing lean body mass. Selenium is a dietary essential trace element with important biological roles; at supranutritional dietary levels, Selenium can prevent the development of many types of cancer. At higher concentrations, Selenium compounds can be either cytotoxic or possibly carcinogenic. The cytotoxicity of Selenium is suggested to be associated with oxidative stress [4].

The supplementation of diets fed to sows with a probiotic preparation; Saccharomyces cerevisiae boulardii recorded non-significant reproductive problems such as abscess, mummies, mortality, stillborn, weak, and abortion [5]. Recently, [5] determine the effect of diets supplemented with Saccharomyces cerevisiae boulardii (Levucell SB). Also, evaluation of yeast culture supplementation in the productivity of sows and piglets during gestation and lactation periods for commercially relevant data is recorded [6].

The comet assay (also called single cell gel assay, SCG and microgel electrophoresis, MGE) is a sensitive and rapid method for double DNA strand break detection in individual cells. It was first introduced as a microelectrophoretic technique to direct the visualization of DNA damage in individual cells [7]. Its use has increased significantly in the past few years and modified to measure the apoptotic DNA damage by estimating the apoptotic fraction [8].

In spite of the safety and good effect of the dietary supplement (yeast tablets) which investigated in the previous literatures, there is no enough and reliable information about the safety of taking brewer's yeast by mouth in pregnant women and their fetuses. So we are encouraged to do this research to investigate the safety of yeast tablets on pregnant women and their fetuses.

\section{MATERIALS AND METHODS}

\section{Drug Used}

Yeast supplements were purchased from Kahira pharmathetical company, Cairo, Egypt. Each tablet contains $66.66 \mathrm{mg}$ of dry yeast which equivalent $500 \mathrm{mg}$ of medical yeast. Yeast supplements were administrated orally using oral stomach tube at a dose of $41.1 \mathrm{mg} / \mathrm{kg}$ corresponding to the human therapeutic dose level.

\footnotetext{
Animals

Virgin female and male albino rats, Rattus norvegicus, weighing about 170-180 g were used in the present investigation. The animals were obtained from the animal
} 
(Implication of yeast tablets on Rats)

house of the Faculty of Veterinary Medicine, Giza, Egypt. Before starting the experiment, animals were allowed to acclimatize for at least 7 days. Pregnancy was established by housing females in the pro-estrous and estrous stages with healthy fertile males over night; 12 -h light/dark cycle (2:1) under controlled environmental condition of temperature $\left(25 \pm 2^{\circ} \mathrm{C}\right)$, humidity $(60 \pm 20 \%)$ and given feed and water $a d$ libitum. The next morning, females with positive vaginal plug or vaginal smears were considered pregnant, and the day of detection was defined as the first day of pregnancy or gestation [9]. Experimental protocols and procedures used in this study were approved by the Cairo University, Faculty of Science, and Institutional Animal Care and Use Committee (IACUC) (Egypt) (CUFS/F/28/15). The animals were handled according to the Guide for the Care and Use of Laboratory Animals, $8^{\text {th }}$ Edition (2011 National Academies Press).

\section{Experimental studies}

Pregnant rats were allocated into two groups (15 per group). The control group received saline water and the experimental group received $41.1 \mathrm{mg} / \mathrm{kg}$ of yeast supplement diluted in saline. The dosing regimen was based on human therapeutic dose (HED). The supplement were administered orally by gavage from day 5 up to 18 of pregnancy, defined as the critical period for the structural development span of the embryonic stage for rats [10]. On gestation day 20, all animals were euthanized with sodium pentobarbital. Cesarean sections were performed on the pregnant rats. Liver, kidney and the gravid uterus were removed from the female. The contents of the gravid uterus were extracted (fetus with its corresponding liver, kidney and placenta). Elimination of foreign substances from the body can occur via any of several routes, most toxic wastes are cleared by elimination of unchanged toxic waste by the kidney and/or by metabolism in the liver. Generally, liver is target organ for metabolism, biotransformation of drugs and detoxification of different components and conversion into the forms that can be readily eliminated from the body (excretion of xenobiotics). It is concerned in wide range of functions and so it is exposed to toxic substances and drugs absorbed from the intestine. After enteric uptake of injurious materials, it is the first organ to be exposed to such hazards via the portal circulation [11]. The kidney possesses most of the common xenobiotic metabolizing enzymes, and is thus able to make an important contribution to the body's metabolism of drugs and foreign compounds [12]. Placenta plays an essential role in fetal development, any kind of placental dysfunction leads to abnormalities in the growth and development of the embryo [13], [14]. The placenta in mammals is the most important channel for the exchange of materials between the maternal and fetal blood [15]. Investigations were carried on collected liver, kidney and placenta as follow:

\section{Histopathological studies}

Fetal and Maternal biopsy of liver, kidney and placenta of the control and treated groups were firstly fixed for histological investigation by light microscopy using; $10 \%$ formalin solution for $24 \mathrm{hrs}$. Washing was done in running water to remove excess fixative then dehydration using serial ascending series of ethyl alcohol. Specimens were cleared in xylene and embedded in paraffin wax at 56 degree in hot air oven. Paraffin bees wax tissue blocks were prepared for sectioning at $5 \mu \mathrm{m}$ thickness using Reichert microtome. The obtained tissue sections were mounted on glass slides, deparaffinized, stained with haematoxylin (Ehrlich) and counterstained by eosin for routine examination by the light microscope [16]. 


\section{Statistical analysis}

Results were expressed as mean \pm S.D. All statistical analysis were done using Statistical Package for the Social Sciences (SPSS) (version 20), the T-test was performed to test the significance level between the treated group and negative control group. Values of $\mathrm{P}<0.001$ were considered statistically significant.

\section{Neutral comet assay}

Apoptotic DNA damage in liver, kidney and placenta was investigated in mother and fetus using neutral comet assay [17]. Briefly, after cells lysis, slides were placed in $1 \times$ TBE buffer ( $90 \mathrm{mM}$ Tris, $2 \mathrm{mM}$ EDTA, $90 \mathrm{mM}$ boric acid, $\mathrm{pH} 8.4$ ) at $4{ }^{\circ} \mathrm{C}$, and electrophoresed. Number of non-apoptotic cells (have no or little DNA migration), apoptotic cells (form structures with large fan-like tails and small heads) and necrotic or heavily damaged cells (have a long, thin tail of fragmented DNA) were scored in one thousand cells per animal. The apoptotic fraction (AF) was calculated as the number of apoptotic cells or necrotic cells / the total number of cells examined.

\section{Single strand conformational analysis (SSCP)}

To screen the presence of mutations in p53 exons 7 and 8, SSCP Analysis were performed in liver and kidney of both mother and fetuses and placenta. First, genomic DNA was extracted using the Gene JET Genomic DNA Purification kit (Thermo Scientific \#K0721, \#K0722) according to the manufacturer's instructions. Proteinase $\mathrm{K}$ was added to the homogenizing tissues, mixed well and incubated at $56^{\circ} \mathrm{C}$ for one hour. After centrifugation, DNA was washed twice and finally eluted using the elution buffer.

The p53 exons 7 and 8 were amplified using the primer sequences sense TGTGCTGTGCCTCCTCTTGTC and antisense GCGCCTCCACCTTCTTTGTCC for exon 7 (198 bp) and sense CCCTTGCTCTCTCCTTCCATA and antisense TTGGTACCTTAAGGGTGAAATA for exon 8 (102 bp) [18]. In the amplification reaction the initial denaturation at $98{ }^{\circ} \mathrm{C}$ for 5 min was followed by 35 cycles of denaturation at $95^{\circ} \mathrm{C}$ for $1 \mathrm{~min}$, annealing at $55^{\circ} \mathrm{C}$ for $1 \mathrm{~min}$ and extension at $72^{\circ} \mathrm{C}$ for $1 \mathrm{~min}$ were performed. Finally, final extension at $72{ }^{\circ} \mathrm{C}$ for $7 \mathrm{~min}$ was performed.

For SSCP analysis PCR products were $20 \%$ polyacrylamide gel electrophoresis (acrylamide: bisacrylamide $=49: 1$ volume/volume). After mixing PCR product with denaturing- loading dye $(95 \%$ formamide, $0.1 \%$ bromophenol blue, $0.1 \%$ Xylene cyanol FF, and 0.5-1 15\% Ficoll) and EDTA buffer, it was denatured at $94^{\circ} \mathrm{C}$ for 5 min and chilled on ice for $10 \mathrm{~min}$. The denatured PCR samples were electrophoresed till the dye reached the bottom of the gel, stained with ethidium bromide and photo was taken using a Polaroid camera (PolaroidMP4 Land Camera).

\section{Statistical analysis}

Results were expressed as mean \pm S.D. All statistical analysis were done using Statistical Package for the Social Sciences (SPSS) (version 20), the T-test was performed to test the significance level between the treated group and negative control group. Values of $\mathrm{P}<0.001$ were considered statistically significant.

\section{RESULTS}

\section{Histopathological estimation to liver}

\section{Maternal liver of untreated group}

The liver of control (vehicle) rats shows a standard structure; the hepatocytes are arranged in trabecules running radiantly from the central vein towards the periphery. The plates of cells are separated by an anastomosing system of sinusoids which 
(Implication of yeast tablets on Rats)

converged towards the central vein and partially lined by Kupffer's cells. The hepatocytes are large polygonal cells, regular in shape and contain a large spherical nucleus. They showed distinctly marked nucleoli and peripheral chromatin distribution. Some cells have two nuclei (Fig.1A).

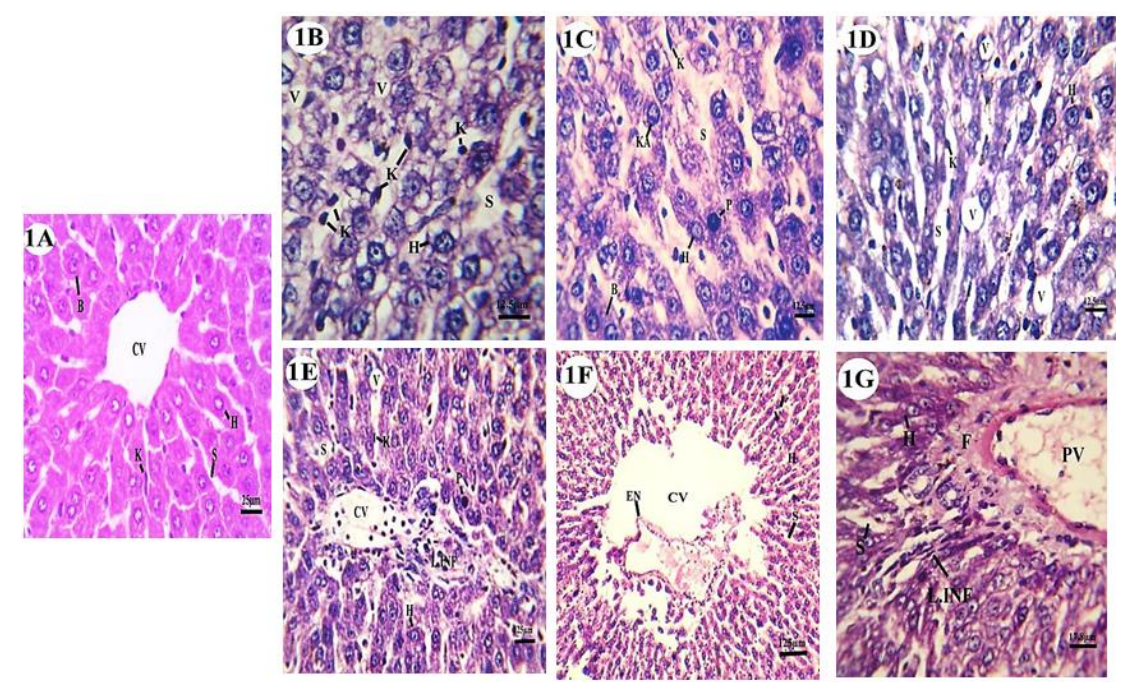

Figure 1 - A: Mother control liver with central vein $(\mathrm{CV})$, regularly arranged hepatocytes $(\mathrm{H})$, some binucleated hepatocytes (B), blood sinusoid (S), and Kupffer's cells (K). B: Treated liver showing fragmentation of nuclear material of some hepatocytes, enlarged Kupffer's cells, wide blood sinusoid and evidence of vaculation (V). C: Treated liver showing condensation of chromatin material in some hepatocytes (pyknosis; P), degeneration of cytoplasmic material of liver cells, enlarged Kupffer's cells and dilatation of blood sinusoid between hepatocytes. D: Treated liver revealed cytoplasmic vacuoles in between hepatic cells and enlarged Kupffer's cells scattered within dilated blood sinusoid. E: Treated liver with lymphatic infiltration (L.INF) around central vein, wide blood sinusoid, evidence of cytoplasmic vacuolation, and pyknosis. F: Treated liver with damage of endothelium (EN) which lining the central vein. G: Treated liver revealed dilatation of blood sinusoid between hepatocytes, fibrosis (F) and lymphatic infiltration in portal space area and portal vein (PV) lined with thick wall of endothelial cells..

\section{Histopathological Changes of Hepatic Tissue of maternal treated group}

The microscopical investigation of liver section of pregnant females which are administrated by the yeast tablets $(41.1 \mathrm{mg} / \mathrm{kg}$ ) showed alterations in its architecture, where different regions exhibited degree of degeneration. These degenerated areas showed dilated and congested sinusoids, with enlarged Kupffer's cells (Figs.1B\&1E), and dissociated hepatocytes with disorganization of the hepatic strands. Inflammatory foci are consisting of necrotic cells with pyknotic cellular nuclei, condensed chromatin material, fragmented chromatin; karyorrhexis, lack of nucleolus (Figs.1C\&1E), vacuolization of the cytoplasm in many hepatocytes (Figs.1D\&1E) and many lymphocytic mononuclear cells infiltration (Figs.1E\&1G). In addition, disruption of central vein wall is evidence with distributed red blood cells and cell debris (Fig.1F). Fibrosis is recognized to some hepatic blood vessels. The portal vein is dilated and congested. The lumen is filled with masses of scattered erythrocytes and cell debris (Fig.1G).

\section{Fetal liver of untreated group}

The fetal liver at $20^{\text {th }}$ day of gestation is covered with a very thin capsule characterized with a single elongated mesothelial cells. It appears as a homogenous mass of parenchyma cells arranged in hepatic lobules separated by interlobular connective tissue septa which are poorly developed. The hepatic lobules are characterized by an irregular branched and interconnected hepatic strands of 1-3 cells thick radiating from the central vein to the lobule periphery. The hepatocytes 
appear more or less polygonal in shape with distinct boundaries having spherical nuclei. The blood sinusoid are irregulary dilated vessels, lined with a discontinuous layer of endothelial cells intervened by large phagocytic Kupffer's cells. In the late embryonic periods, liver acts as a hemopoietic organ, with few megakaryocytes and considerable numbers of erythroblasts in different developmental stages (Fig.2A).
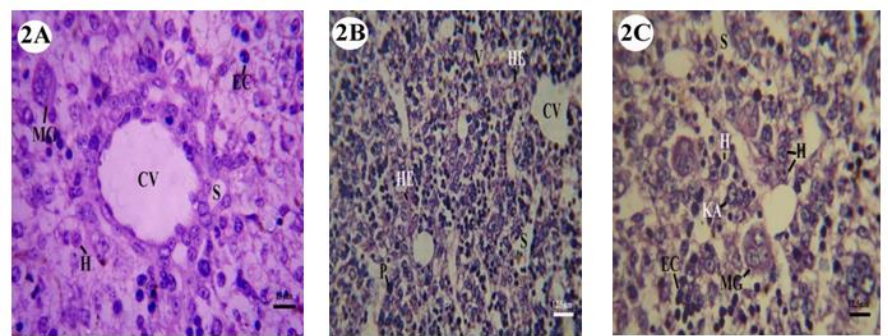

Figure 2 - A: Fetus control liver showing central vein, normal hepatocytes with blood sinusoid, megakaryocyte (MG), and erythrocytes (EC). B: Fetus treated liver with hemorrhagic sites (HE), wide blood sinusoid, vaculation and pyknosis. C: Fetus treated liver with degeneration in cytoplasmic material and fragmentation in genetic material of hepatocytes (karyolysis; KA), multiple megakaryocytes and many of erythrocytes

\section{Histopathological Changes of Hepatic Tissue of fetus}

Examination of the liver of fetus,maternally orally administrate with yeast tablets, revealed congestion of the blood vessels and blood sinusoid, through which blood escaped, causing an evidence of hemorrhagic site A sign of degeneration was observed by the presence of numerous vacuoles in the cytoplasm of hepatocytes, karyolysis and pyknosis in hepatic cells (Figs.2B\&2C). In addition, distribution of megakaryocytes was observed (Fig.2C). Most of the endothelial cells lining the sinusoids are markedly eroded and ruptured. The liver of this group showed marked loss of the lobular architecture and disorganization of the hepatic strands.

\section{Histopathological estimation to kidney \\ Maternal kidney of untreated group}

Microscopic examination of the kidney of untreated pregnant mother showed normal structure (Fig.3A). 


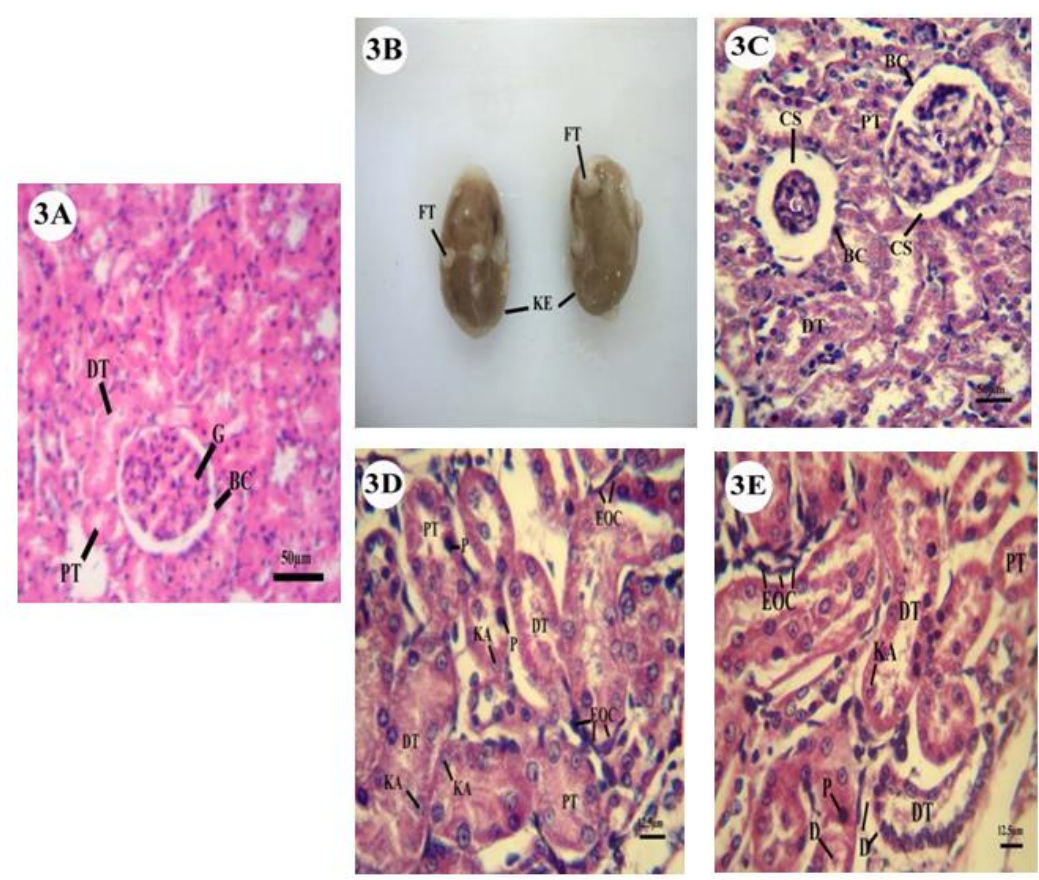

Figure 3 - A: Mother control kidney showing glomeruli (G) within Bowman's capsule (BC), distal (DT), and proximal tubules (PT). B: Photomicrograph of mother treated kidney (KE) showed accumulation of fatty tissues (FT) on its surface. C: Mother treated kidney revealed decrease and increase in capsular space (CS) of Bowman's capsule due to swollen and shrinkage in glomeruli. D: Mother treated kidney with karyolysis, pyknosis in endothelial cells and scattering of eosinophilic cells (EOC). E: Mother treated kidney showing degeneration of cytoplasmic material (D) in endothelial cells lining distal and proximal tubules, scattering of eosinophilic cells, karyolysis and pyknosis also evident.

\section{Histopathological Changes of kidney (renal) Tissues of maternal treated group}

The examination of kidney in treated pregnant mother showed significant changes. Morphologically, patches of fatty tissue appeared on the external surface of kidney (Fig.3B). Histologically, there was shrinkage in the glomeruli (congestion) leading to the appearance of large space (widened in capsular urinary space) between the blood capillaries of glomeruli and Bowman's capsule (Fig.3C). The cells of proximal and distal convoluted tubules (Fig.3D) showed degree of degeneration represented by complete or partial damage to nuclei (karyolysis). Condensation in nuclear material was also observed (pyknosis). In addition, the cytoplasmic part of cells in distal tubules was dissolute (Fig.3E). Aggregates and scatters of eosinophilic cells between Bowman's capsule and convoluted tubules were recorded (Figs.3D\&3E).

\section{Fetal kidney of untreated group}

Examination of the fetal kidney at $20^{\text {th }}$ day of gestation revealed that it is differentiated into an outer cortex and an inner medulla. The cortex appears in radial striations, the rays of medulla are extending from the base of the pyramids without reaching the renal capsule. Each medullary pyramid with the corresponding part of the cortex represents a renal lobe which formed from the uriniferous tubules and stromal connective tissue. The uriniferous tubule (mesonephric unit) is formed of Malpighian corpuscle, the proximal convoluted tubule, the descending and the ascending limbs of Henle's loop and the distal convoluted tubule. Each corpuscle consists of glomerulus and Bowman's capsule separated by distinct capsular space. The proximal convoluted tubules are rounded with single layer of short columnar cells with unclear cell boundaries, spherical nuclei and well developed brush borders that fill the lumen of the corresponding tubules. While, the distal convoluted ones are 
lined with simple cuboidal epithelial cells that characterized by clear cell boundaries, a granular cytoplasm and spherically centrally position nuclei (Fig.4A).
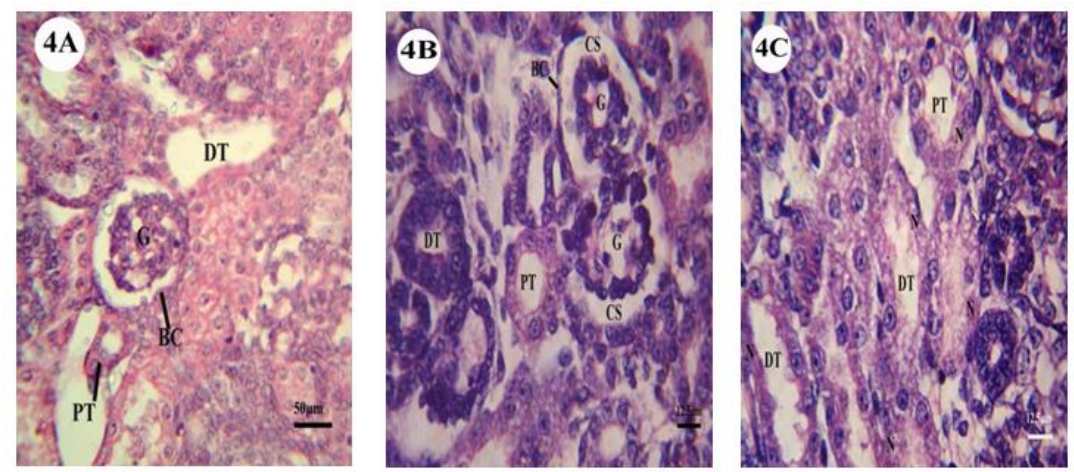

Figure 4 - A: Fetus control kidney showing Bowman's capsule with its glomeruli, distal, and proximal tubules. B: Fetus treated kidney with decrease and increase in capsular space of Bowman's capsule due to swollen and shrinkage in glomeruli. Degeneration in nuclear and cytoplasmic material of tubules was observed. C: Fetus treated kidney revealed necrotic change $(\mathrm{N})$ in distal and proximal tubules.

\section{Histopathological Changes of renal Tissue of fetus}

Examination of the embryonic kidney of maternally orally administrated yeast tablets revealed the shrunken and swollen glomeruli with wide and narrow capsular spaces, respectively (Fig.4B). Distinct pathological lesions were recorded in the uriniferous tubules (Figs. 4B\&4C). The lining cells of the two types of convoluted tubules exhibited cloudy swelling, degeneration and cellular necrosis. The outer borders of the cells lining the convoluted tubules were deteriorated.

\section{Histopathological estimation to placenta}

The placenta is a transitionary tissue, configuring from a maternal portion and a fetal one. Without any administration to yeast tablets, there was no significant difference between the ratio of labyrinth area and the area occupied by spongiotrophoblasts (Fig.5A). The administration of supplementary tablet of yeast at human dose showed alteration in the different zones at some degree in placenta; trophoblastic giant cells showed degenerative characters; the cytoplasmic material of giant cells showed many heterogenous vacuolations, and the nuclei of it were karyolitic (Fig.5B). In the basal zone, increases in spongiotrophoblasts, clusters of glycogen cells and hyperemia (hemorrhagic cyst) were observed (Fig.5C). Also, there were increases in the number of apoptotic cells characterized by karyorrhexis in this zone (Fig.5C). In the labyrinth area, decrease and irregular vessel formation and an irregular dilatation of maternal sinusoids were observed. Damage in the corresponding zone became marked with degeneration and necrosis. Accumulation of cell's debris was detected (Fig.5D). Degeneration of epithelial cells line the fetal blood vessels was detected (Fig. 5E). 

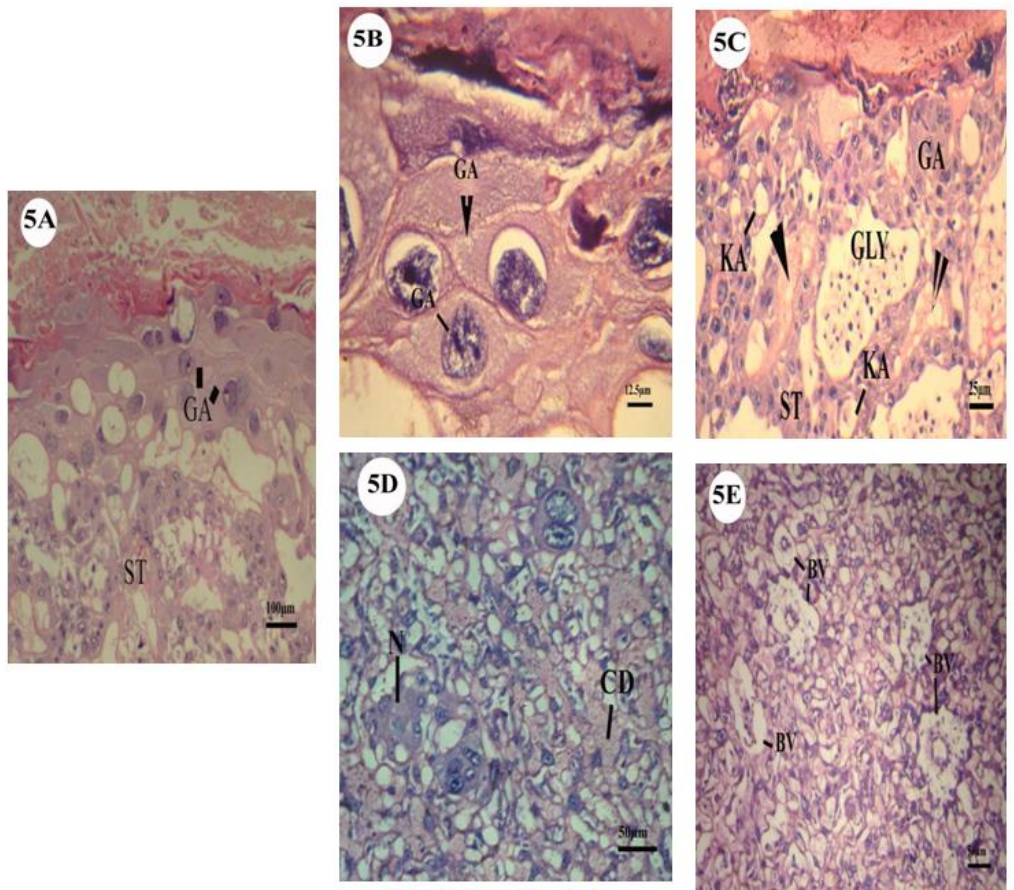

Figure 5 - A: Control placenta with giant cells (GA) and spongitrophoblast (ST). B: Treated placenta with fragmentation in nuclear material of giant cell as indicated by line and vaculation in cytoplasm of giant cell as indicated by head arrow. C: Treated placenta showing accumulation of glycogen granules within enlarged vacuoles, accumulation of blood within it as indicated by head arrow, and with karyolitic cells as indicated by line in spongitrophoblast. D: Treated placenta with necrotic area and cellular debris (CD). E: Treated placenta revealed degeneration in epithelial cells of fetal blood vessels (BV).

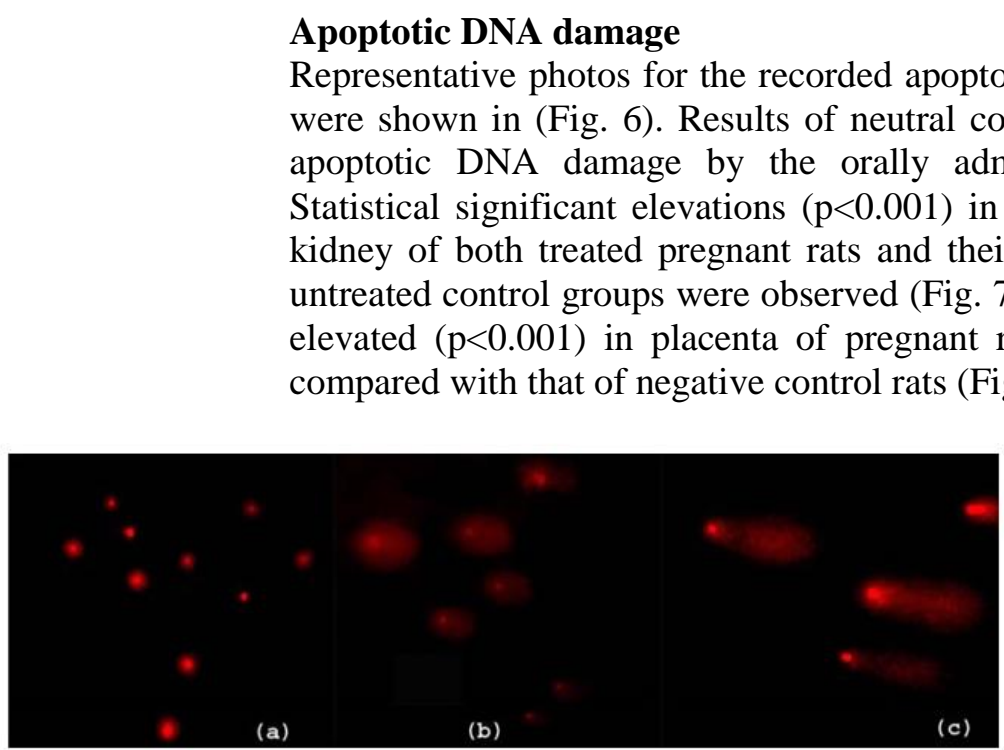

Figure 6- Representative photo for the observed scored comet nuclei (a) non apoptotic (b) apoptotic and (c) necrotic cells. 


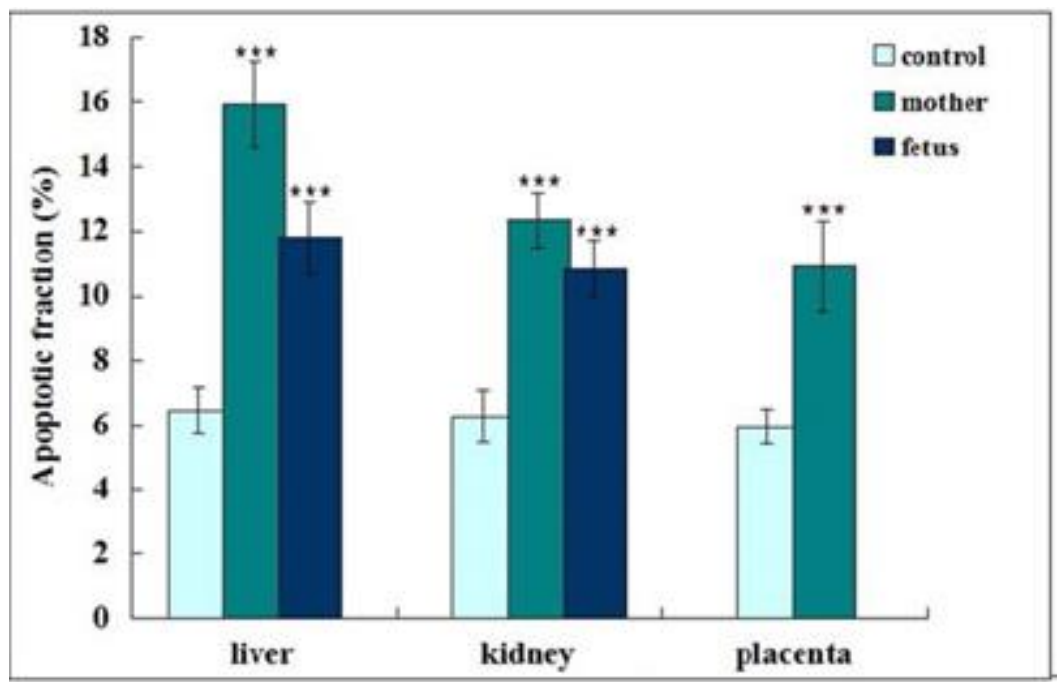

Figure 7- Apoptotic fraction in pregnant rats treated with yeast $(41.1 \mathrm{mg} / \mathrm{kg})$ and their fetuses. ***: Statistically significantly different from the negative control group at $\mathrm{p}<0.001$ using t-test.

\section{SSCP analysis}

Results of SSCP analysis showed that oral administrations of yeast $(41.1 \mathrm{mg} / \mathrm{kg}) \mathrm{did}$ not result in the induction of any mutation in the p53 exons 7 and 8 in both treated pregnant rats and their fetuses. The PCR-SSCP patterns of both exons 7 and 8 were the same in treated pregnant rats, their fetuses and the negative control group (Fig. 8).

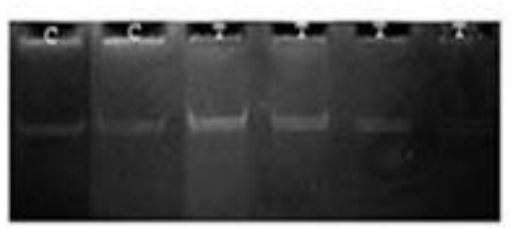

Exon 7

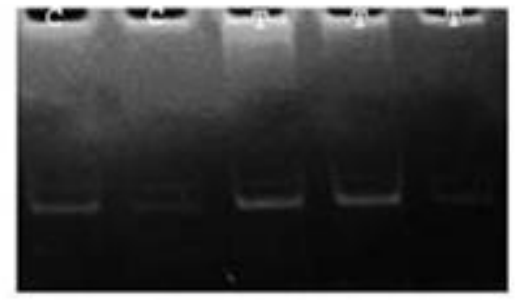

Exon 8

Figure 8- Representative 20\% polyacrylamide gel for PCR-SSCP pattern for p53 exon 7\&8. C: negative control and T: treated sample

\section{DISCUSSION}

According to the importance of liver [19] and kidney to get ride the body from toxic substance, in addition to the importance of placenta for normal fetal growth. We focus on them in our current research.

Yeast Viet Tablets supply the maximum daily dose of vitamins B1 (thiamine hydrochloride), B2 (riboflavin) and B3 (nicotinamide/niacin) and contain chromium as well as the mineral selenium.

Trivalent chromium [Cr (III)] salts are used as micronutrients and dietary supplements. Bad developmental effects in animals include cleft palate, hydrocephalus, delayed ossification, edema, and incomplete neural tube closure [20]. In light of most recent studies considering chromium one of active ingredients in yeast tablets, [21] conclude that $\mathrm{Cr}$ (III) can directly cause genetic mutations in yeast and Jurkat cells. In contrast, $\mathrm{Cr}$ (III) was initially considered a relatively nontoxic 
agent that plays an important role in regulating blood glucose levels and is regarded as a dietary supplement [22], [23]. Studies in cell-free systems demonstrated that $\mathrm{Cr}$ (III) does bind to DNA, leading to a decrease in the fidelity and an increase in the processivity of DNA polymerases, which may ultimately lead to increased mutations [24]. While, the potential for genotoxic side-effects of $\mathrm{Cr}$ (III) complexes may outweigh their possible benefits as insulin enhancers and that recommendations for their use as either nutritional supplements or antidiabetic drugs need to be reconsidered [25]. Also, Data in vitro studies show that $\mathrm{Cr}$ (III) has the possibility to react with DNA and responsible for DNA damage in cell culture systems, but under normal conditions, restricted access of $\mathrm{Cr}$ (III) to cells in vivo minimize or prevents genotoxic effect in the biological systems. The available in vivo evidence suggests that genotoxic effects are very unlikely to occur in humans or animals exposed to nutritional or to moderate recommended supplemental levels of trivalent chromium [26].

Comparative studies of chromium (III) picolinate and niacin-bound chromium(III), two popular dietary supplements, reveal that chromium (III) picolinate enhanced production of hydroxyl radicals, chromosomal aberration, depletion of antioxidant enzymes, and DNA damage [27]. Also in another study [28] proved that nutritional supplement chromium picolinate generates oxidative DNA damage and peroxidized lipids in vivo.

Selenium (Se) is a dietary essential trace element with important biological roles. Selenium element is an important in normal cellular function, but using selenium in a liquid dietary supplement in toxic concentrations in a widely. Had the manufacturers been held to standards used in the pharmaceutical industry, it may have been stopped [29]. In addition, studies prove that selenium has significant toxicity if ingested in large amounts [30]. Also, epidemiological surveys have cleared that, the deficiency in selenium intake causing serious disease of the cardiovascular, osseous, and damage in nervous and immune systems of the fetus [31].

Developmental toxicity of selenium (Se) is a nutritional, environmental and medicinal concern. [32] investigated Se embryotoxicity of cultured rat embryos using proteomic analysis. Embryonic susceptibility to selenium (Se) teratogenicity was examined in rats using postimplantation embryo culture. Rat embryos exposed to Se compounds showed abnormalities such as deformed optic vesicle and swollen rhombencephalon in the viable embryos. These abnormalities were considered to correspond to in vivo malformations caused by Se in hamster fetuses or in bird embryos [33]. Pregnant rabbits and hamsters were treated with selenite, selenate, and selenomethionine during the critical stages of embryogenesis causing a specific teratogenic effect to selenium is confounded by maternal toxicity [34], [35]. While, in studies on monkeys (Macaca fascicularis) fed selenomethionine with 3 different doses $(25,150$ or $300 \mu \mathrm{g} / \mathrm{kg}$ of body weight per day) during organogenesis, no evidence of teratogenicity were recorded [36]. The previous study carried by [37] showed embryotoxic and teratogenic effects when Mallards (Anas platyrhynchos) were fed a diet containing a selenium source. These malformations included hydrocephaly, microphthalmia, lower bill defects, and foot defects with ectrodactyly. Also, increased the incidence of edema and stunted embryonic growth.

Selenium is a potent reproductive and teratogenic environmental contaminant. [38] revealed Selenium-induced teratogenicity in Sacramento splittail. Exposed fish had pericardial edema and deformities of skeletal tissues (loss of tail, lordosis, scoliosis, and kyphosis). Other histological alterations were limited to dysplasia, hyperplasia and metaplasia of skeletal tissues in the deformed fish. The effects of Se compounds on cells are strictly compositional and concentration-dependent. At supranutritional 
dietary levels, Se can prevent the development of many types of cancer. At higher concentrations, Se compounds can be either cytotoxic or possibly carcinogenic. The cytotoxicity of Se is suggested to be associated with oxidative stress [39]. Also [40] Suggest that high dietary intake of inorganic Se may promote in vivo DNA oxidation.

Selenite, selenate and selenide induced unscheduled deoxyribonucleic acid (DNA) synthesis, sister chromatid exchange and chromosomal aberrations in cell cultures in vitro, often in the presence of glutathione [41], [42], [43]. At toxic doses, in one in vivo study, chromosomal aberrations and increased sister chromatid exchanges were seen in hamster bone marrow cells after selenite treatment [44].

The first parts of discussion refer to the advances and the harm effects to the composition ingredients to yeast tablets which act as ones of the dietary supplements. In addition to the time period of administration which is the occurrence of the neural plaque to closure of the plate. It begins usually on the $18^{\text {th }}-21^{\text {st }}$ days in human being, prolongs nearly 36 days. Likewise, it starts on the 6th day in rats, going on for 10 days [45]. During this process, teratogenic agents can lead significant irreversible congenital anomalies.

Placental growth and function affect biological significance in the pregnant maintenance and prenatal life. Therefore, chemical-induced alteration or deviation of placental function in the maternal and extraembryonic tissue can ultimately lead to pregnancy loss, congenital malformation and fetal death. The current work showed histopathological changes in the placenta tissue that represented in degenerative changed in the labyrinth zone, at which the maternal and fetal bloods come very close together, play pivotal roles in the maternal-fetal exchange, placental xenobiotic metabolism, placental endocrine function and placental barrier of substances [46]. The dysfunction of the labyrinth zone is known to cause adverse effects on embryonic developments.

Liver is the first target organ for toxicological prospects because of its role in detoxification, biotransformation and excretion of xenobiotics. Our study showed that abnormal histology in liver of treated group. The observed changes including leukocyte infiltrations activated Kupffer's cells, dilatation in blood sinusoids and extensive cytoplasmic vacuolization. In this study also reported that administration of yeast tablets resulted in glomerular necrosis of the maternally kidney tissue, also the fetal kidney showed destruction of renal tubules cells and convoluted tubules showed degenerative changes that may be due to the renal tubules come in contact with the chemicals during the execration and elimination [47]. Necrosis occurrence may be accompanied by ATP depletion that caused cells death [48] due to chromium and selenium as integrated parts of yeast tablets.

Ethyl carbamate (EC) is a chemical contaminant naturally formed in fermented foods as a byproduct of fermentation or during storage e.g. bread, soy sauce and yogurt, and in alcoholic beverages such as spirits, wine and beer [49]. It is a genotoxic mutagen both in vitro and in vivo experimental system [50] and has been shown to induce chromosomal aberrations, micronuclei and sister chromatid exchange [51]. Consequently, our finding of yeast induced apoptotic DNA damage in both pregnant rats and their fetuses revealed by the high apoptotic fractions could be attributed to EC production primarily from the reaction of alcohol (ethanol) with urea and its break-down products as yeast converts sugars and starch into carbon dioxide and alcohol. 


\section{CONCLUSION}

This article showed the possible implications arising from intake of dietary supplement (yeast tablets) on the pregnant rats and their fetuses. So, the authors recommend that the yeast tablets should be given with caution.

\section{AKNOWLDGEMENT}

This paper was supported by Comparative Anatomy and Embryology and Molecular Biology Laboratories, Zoology Department, Faculty of Science, Cairo University.

\section{FINANCIAL AND CONFLICTS OF INTEREST DISCLOSURE}

The author has no relevant affiliations or financial involvement with any organization or entity with a financial interest in or financial conflict with the subject matter or materials discussed in the manuscript apart from those disclosed. No writing assistance was utilized in the production of this manuscript.

\section{REFERENCES}

1. Broadway PR, Carroll JA, Sanchez NCB. Live Yeast and Yeast Cell Wall Supplements Enhance Immune Function and Performance in Food-Producing Livestock: A Review. Microorganisms 2015, 3, 417-427. [Cross Ref ]

2. Delcenserie V, Martel D, Lamoureux M, Amiot J, Boutin Y, Roy D. Immunomodulatory effects of probiotics in the intestinal tract. Curr Issues Mol Biol. 2008, 10, 37-54. [PubMed]

3. Vincent JB. Polyhedron. 2001, 20, 1-26. [PubMed]

4. Lucia L, Viera V, Jela B. Selenium: From cancer prevention to DNA damage. Toxicology 2006, 227,1-14. [Cross Ref]

5. Lipiński K, Chrostowski G, Matusevičius P, Skórko-Sajko H, Stasiewicz M, Purwin C, Pysera B. The effect of diets supplemented with saccharomyces cerevisiae boulardii probiotic yeast on the reproductive performance of pregnant and lactating sow. veterinarija ir zootechnika. 2012, 59, (81). [Cross Ref ]

6. Kim SW, Brandherm M, Freeland M, Newton B, Cook D, Yoon I. Effects of Yeast Culture Supplementation to Gestation and Lactation Diets on Growth of Nursing Piglets. AsianAust J Anim Sci. 2008 ,21, 1011 - 1014. [Cross Ref ]

7. Fairbairn DW, Olive PL, O'Neill KL. The comet assay: a comprehensive review. Mutation Research 1995, 339, 37-59. [PubMed]

8. Attia SM, Al-Bakheet SA, Al-Rasheed NM. Proanthocyanidins produce significant attenuation of doxorubicin-induced mutagenicity via suppression of oxidative stress. Oxid Med Cell Longev. 2010, 3, 404-413. [Cross Ref ]

9. McClain RM, Becker BA. Teratogenicity, fetal toxicity, and placental transfer of lead nitrate in rats. Tox Appl Pharmacol. 1975, 31, 72-82. [Cross Ref ]

10. WHO (World Health Organization) Principles for evaluating health risks to reproduction associated with exposure to chemicals. Environmental Health Criteria 2001, 225, 1-187. [Cross Ref]

11. Katzung, BG. Basic and clinical pharmacology, $3^{\text {rd }}$ ed, Appleton and lang, connreticut, USA. 1990.

12. Lock EA, Reed CJ. Xenobiotic Metabolizing Enzymes of the Kidney. Toxicologic Pathology 1998, 26(1): 18-25.

13. Roloff DW, Howatt W F, Kanto WP, Borker Jr. RC. "Morphine administration to pregnant rabbits: effect on fetal growth and lung development," Addictive Diseases 1975, 2(1-2): 369-379. 
14. Collins L.R, Hall RW, Dajani NK, Wendel PJ, Lowery CL, Kay HH. "Prolongedmorphineexposureinuterocauses fetal and placental vasoconstriction: a case report," Journal of Maternal-Fetal and Neonatal Medicine 2005, 17(6): 417-421.

15. Dehghani L, Sahraei H, Meamar R, Kazemi M. Time-Dependent Effect of Oral Morphine Consumption on the Development of Cytotrophoblast and Syncytiotrophoblast Cells of the Placental Layers during the Three Different Periods of Pregnancy in Wistar Rat. Clinical and Developmental Immunology, 2013: 974205.

16. Banchroft JD, Steven A, Turner DR. Theory and practice of histological techniques. Fourth Ed., London, San Francisco, Tokyo: Churchill Livingstone:New York. 1996. [Cross Ref ]

17. Kizilian NRC, Wilkins P, Reinhardt C, Ferrarotto JRN, McLean JP. Mc- Namee Silverstained comet assay for detection of apoptosis. Biotechniques 1999, 27, 926-929. [Cross Ref ]

18. Castelli EC, Otake AH, Elgui de Oliveira D, Rocha NS, Fávero Salvadori DM, Viana de JL. Camargo. No mutations found in exons of TP53, H-RAS and K-RAS genes in liver of male Wistar rats submitted to a medium-term chemical carcinogenesis assay. Rio de Janeiro. 2002, 38,175-182. [Cross Ref]

19. Katzung BG. Basic and clinical pharmacology. USA. 3rd ed, Appleton and lang, connreticut. 1990. [Cross Ref]

20. ATSDR (Agency for Toxic Substances and Disease Registry) What Are the Physiologic Effects of Chromium Exposure? 2008. [Cross Ref]

21. Fang Z, Zhao M, Zhen H, Chen L, Shi P, Huang Z. Genotoxicity of Tri- and Hexavalent Chromium Compounds In Vivo and Their Modes of Action on DNA Damage In Vitro. PLoS ONE 2014, 9(8). [PubMed]

22. Althuisfs MD, Jordan NE, Ludington EA, Wittes JT. Glucose and insulin responses to dietary chromium supplements: a meta-analysis. Am J Clin Nutr. 2002, 76,148-155. [PubMed]

23. Cefalu WT, Hu FB. Role of chromium in human health and in diabetes. Diabetes Care 2004, 27, 2741-2751. [PubMed]

24. Langard S. One hundred years of chromium and cancer: a review of epidemiological evidence and selected case reports. Am J Ind Med. 1990, 17,189-215. [PubMed]

25. Levina A, Lay P. Chemical properties and toxicity of chromium (III) nutritional supplements. Chem Res Toxicol. 2008, 21: 563-571. [PubMed]

26. Eastmond, DA, MacGregor JT, Slesinski RS. Trivalent Chromium: Assessing the Genotoxic Risk of an Essential Trace Element and Widely used Human and Animal Nutritional Supplement. Crit Rev Tox. 2008, 38 (3), 173-190. [PubMed]

27. Debasis B, Sidney JS, Bernard WD, Manashi BP. Cytotoxicity and oxidative mechanisms of different forms of chromium. Toxicology 2002, 180 (1), 1 5-22. [PubMed]

28. Dion DDH, Marcel B, Stephen AW, John BV. The nutritional supplement chromium picolinate generates oxidative DNA damage and peroxidized lipids in vivo. Polyhedron. 2003, 22(1), 455-463. [Cross Ref]

29. MacFarquhar JK, Broussard DL, Melstrom P, Hutchinson R, Wolkin A, Martin C, Burk RF, Dunn JR, Green AL, Hammond R, Schaffner W, Jones TF. Acute Selenium Toxicity Associated With a Dietary Supplement. Arch Intern Med. 2010, 170,256-261. [PubMed]

30. Aldosary BM, Sutter ME, Schwartz M, Morgan BW. Case series of selenium toxicity from a nutritional supplement. Clin Toxicol (Phila). 2012, 50, 57-64. [PubMed]

31. Pieczyńska J, Grajeta $H$. The role of selenium in human conception and pregnancy. $J$ Trace Elem Med Biol. 2015, 29:31-8. [PubMed]

32. Usami M, Mitsunaga K, Nakazawa K, Doi O. Proteomic Analysis of Selenium Embryotoxicity in Cultured Postimplantation Rat Embryos. Birth Defects Research (Part B) 2008, 83, 80-96. [PubMed]

33. Makoto U, Yasuo O. Teratogenic Effects of Selenium Compounds on Cultured Postimplantation Rat Embryos. Teratogenesis, Carcinogenesis, and Mutagenesis 1996, 16, 27-36. [PubMed] 
(Implication of yeast tablets on Rats)

34. Berschneider F, Willer S, Hess M, Neuffer K. Fetale und maternal Schadewirkungen bei Kaninchen nach Applikation Natriumselenit, Uroselevitt pro inj. Und Uroselevit-Prämix. Monatsch Veterinaermed. 1977, 8, 299-304. [Cross Ref ]

35. Ferm VH, Hanlon DP, Willhite CC, Choy WN, Book SA. Embryotoxicity and doseresponse relationships of selenium in hamsters. Reprod Toxicol. 1990, 4, 183-190. [PubMed]

36. Tarantal AF, Willhite CC, Lesley BL, Murphy CJ, Miller CJ, Cukierski MJ, Book SA, Hendrickx AG. Developmental toxicity of L-selenomethionine in Macaca fascicularis. Fund Appl Toxicol. 1991, 16, 147-160. [PubMed]

37. David JH, Gary HH. Embryotoxic and teratogenic effects of selenium in the diet of mallards. Journal of Toxicology and Environmental Health 1988, 24(4). [PubMed]

38. Swee JT, Xin D, Foo-ching T, Silas OH. Selenium-induced teratogenicity in Sacramento splittail (Pogonichthys macrolepidotus). Marine Environmental Research Little River, 2002, 54,605-608. [Cross Ref]

39. Lucia L, Viera V, Jela B. Selenium: From cancer prevention to DNA damage. Toxicology 2006, 227,1-14. [PubMed]

40. Benjamin JW, Michael AM, Merrill JC. High Dietary Intake of Sodium Selenite Induces Oxidative DNA Damage in Rat Liver. Nutrition and Cancer 2004, 48(1). [PubMed]

41. Ray JH, Altenburg LC. Sister-chromatid exchange induction by sodium selenite: dependence on the presence of red blood cells or red blood cell lysate. Mutation Research 1978, 54,343-354. [PubMed]

42. Whiting R, Wei L, Stich HF. Unscheduled DNA synthesis and chromosome aberrations induced by inorganic and organic selenium compounds in the presence of glutathione. Mutation Research 1980, 78,159-169. [PubMed]

43. Khalil AM. The induction of chromosome aberrations in human purified peripheral blood lymphocytes following in vitro exposure to selenium. Mutation Research 1989, 224,503506. [PubMed]

44. Norppa H, Westermark T, Knuutila S. Chromosomal effects of sodium selenite in vivo.Nutritional Supplement. Crit Rev Tox. 1980, 38,173-190. [Cross Ref]

45. Vickers M, Brackley K. Drugs in pregnancy. Curr Obstet Gynaecol. 2002; 12, 131-7.

46. Takata K, Fujikura K, Shin B. Ultrastructure of the rodent placental labyrinth: a site of barrier and transport. J Repro Dev. 1997, 43, 13-24. [Cross Ref]

47. Tisher CC, Brenner BM. Renal Pathology with Clinical and Functional Correlation. Philadelphia, USA. J. B. Lippincott Company. 1989. [Cross Ref]

48. Sanchez NCB, Young TR, Carroll JA, Corley JR, Rathmann RJ, Johnson BJ. Yeast cell wall supplementation alters the metabolic responses of crossbred heifers to an endotoxin challenge. Innate Immun. 2014, 20, 104-112. [Cross Ref]

49. JECFA (A meeting of the Joint FAO (Food and Agriculture Organization of the United Nations)/ WHO (World Health Organization) Expert Committee on Food Additives) Evaluation of certain food contaminants: sixty-fourth report of the Joint FAO/WHO Expert Committee on Food Additives. WHO technical report series no. 930. Geneva: World Health Organization. 2006. [Cross Ref]

50. IARC (International Agency for Research on Cancer) Urethane. IARC Monographs on the Evaluation of the Carcinogenic Risks of Chemicals to Humans: Alcohol Consumption and Ethyl Carbamate. Volume 96. World Health Organization. IARC. Lyon, France. 2010. [Cross Ref]

51. JECFA (A meeting of the Joint FAO (Food and Agriculture Organization of the United Nations)/WHO (World Health Organization) Expert Committee on Food Additives). Joint FAO/WHO Expert Committee on Food Additives JECFA 64th Meeting, Rome, 81February. 